\title{
La sociedad sacrificial
}

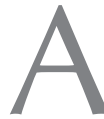
nivel mundial estamos inmersos en una escalada de violencia de proporciones cada vez mayor. Nuestro país está sufriendo esta escalada de violencia a la que los epítetos de maldita, irracional y cobarde se quedan cortos e insuficientes. Lejos está la violencia actual de ser irracional, tiene una racionalidad y es completamente lógica en el marco de una sociedad sacrificial.

En el siguiente análisis sobre la violencia en la sociedad sacrificial, quizá podamos encontrar alguna explicación a nuestra agresiva convivencia humana.

René Girard, en su texto La violencia y lo sagrado (Anagrama, Barcelona, 2005 ) estudia el fenómeno de la violencia como elemento fundamental de las sociedades primitivas en la medida que ante un acto violento se respondía con una venganza de parte de los ofendidos, el ciclo de la violencia podía extenderse hasta acabar con aquella sociedad, es en este punto donde entra la idea de sacrificio porque justo el sacrificio funciona como un engaña-violencia que logra parar, aunque sea momentáneamente, el ciclo de la violencia social. Los sacrificios de animales y los sacrificios de humanos cuando las sociedades primitivas los ofrecían era con el fin de poner paro a la violencia, además, entre las cualidades de este engaña-violencia está el atraer la violencia que se dirige a otros (familia, comunidad, sociedad), a fin de evitarla, o, al menos para distraerla, ya que ahí concluye la venganza, puesto que ella es una víctima por la que nadie se vengará.

Desde la tradición de la literatura trágica de los griegos pasando por la biblia cristiana hasta llegar a los estudios etnográficos recientes el mecanismo sacrificial o engañaviolencia se nos revela como un elemento omnipresente configurando nuestra convivencia social. En la sociedad moderna aparentemente estas prácticas "anti-civilizadas" se han superado pero no es cierto, sí se han refinado las prácticas sacrificiales pero no se han abandonado. Es cierto que hoy si alguno de nosotros es ofendido no podemos tomar la justicia por nuestra propia mano, pues hay un sistema jurídico y legal y un estado de derecho que 
impiden el ciclo de la violencia y de venganza. Dadas las circunstancias críticas en las que asistimos al ocaso del concepto de Estado moderno a partir del fenómeno de la globalización económica y sus mecanismos deshumanizantes tengo varias razones para pensar que nuestro país, nuestro continente y en general nuestro mundo colapsado por la ambición económica de unos pocos sigue viviendo de ofrecer sacrificios del tipo engañaviolencia: el sistema económico neoliberal y sus sacerdotes y gurús enquistados en lo alto del poder político exigen tributos y la sociedad no tiene más que evitar su furia, hay que buscar evadir esa furia y violencia, hay que re-dirigirla pero nos preguntamos ¿hacia quién? ¿Quién será la víctima sacrificial? ¿Sobre quiénes caerá la violencia insaciable? ¿Quién o quiénes serán los malditos? Esta sociedad debe buscar su propio engaña-violencia y no nos engañemos: todos lo sabemos: son los parias, los excluidos, los desechos humanos que ya no tienen lugar en el engranaje económico que ha encontrado la manera de funcionar mejor sin ellos; en nuestra sociedad salvadoreña son todos los subempleados, los que paran en la economía informal, los que deambulan por las calles y ya no nos dicen nada, son como zombis, una especie de muertos vivientes. Y la razón es sencilla: por ellos nadie clamará venganza. Girard nos dice que una sociedad sacrificial es aquella en la que "el sacrificio tiene una función real y el problema de la sustitución se plantea al nivel de toda la colectividad. La víctima no sustituye a tal o cual individuo especialmente amenazado, no es ofrecida a tal o cual individuo especialmente sanguinario, sustituye y se ofrece a un tiempo a todos los miembros de la sociedad por todos los miembros de la sociedad. Es la comunidad entera la que el sacrificio protege de su propia violencia, es la comunidad entera la que es desviada hacia unas víctimas que le son exteriores" (Pág.15). Todo el estado de derecho se encarga de proteger a unos pocos y de hacer que la violencia de recambio Ilegue al indicado: casi siempre las víctimas de la violencia pertenecen a un grupo que no es el propio, siempre son ajenos a nosotros...los revoltosos, los pandilleros, los vendedores, los sindicalistas, etc., etc.; todos ellos son ajenos a nosotros y hay que dirigir nuestra violencia hacia ellos.

Girard introduce la hipótesis de la víctima por sustitución:

"todas las características que hacen terrorífica la violencia, su ciega brutalidad, la absurdidad de sus desenfrenos, no carecen de contrapartida; coinciden con su extraña propensión a arrojarse sobre unas víctimas de recambio" (pág.12) el mecanismo de sustitución permite de alguna 
manera burlar la violencia: "permiten engañar a esta enemiga y arrojarle, en el momento propicio, la ridícula presa que la satisfará" (pág. 12). Ante los atentados de las Torres gemelas en Nueva York, ante otros muchos hechos violentos como el incendio de un bus con todo y sus ocupantes, todos piden que se pare la violencia con más violencia y es que "existe un común denominador de la eficacia sacrificial (...) Este denominador es la violencia intestina; son la disenciones, las rivalidades, los celos, las peleas entre allegados lo que el sacrificio pretende ante todo eliminar, pues restaura la armonía de la comunidad y refuerza la unidad social" (P.16) La pregunta que le hago a esta sociedad civilizada que pide muerte para vivir es si realmente lo vamos a lograr con un estado de derecho excluyente, corrupto y que muchas veces entra en contubernios con los poderes económicos. Bajo el sistema económico actual las víctimas son doblemente víctimas ya que ellos son los afectados directos de la configuración socioeconómica y al mismo tiempo se les convierte en sustitutos de los genuinos causantes de la espiral de violencia, el poder judicial actúa como intermediario entre el poder político y el económico y con ello "la sociedad intenta desviar hacia una víctima relativamente indiferente, a una víctima "sacrificable", una violencia que amenaza con herir a sus propios miembros, los que ella pretende proteger a cualquier precio" (P.12)

Nuestra civilización moderna es más sacrificial que ninguna otra antes, y nuestro país no escapa de esa maldición. 